Bull. Egypt. Soc. Physiol. Sci. Vol. (41), Issue (4), 458-469

\author{
Bull. of Egyp. Soc. Physiol. Sci. \\ (Official Journal of Egyptian Society for Physiological Sciences) \\ (pISSN: 1110-0842; eISSN: 2356-9514)
}

\title{
Paraoxonase 1 Q192R (A/G) Gene Polymorphism as possible risk factor for coronary heart diseases among Egyptians. Case-control study
}

\author{
Sherif Arafa ${ }^{1,}$ Amal Kamel seleem ${ }^{2}$,Lamiaa M. Elabbasy ${ }^{3}$, Kholoud Awad Gad \\ ${ }^{4}$,Sherehan Abdelsalam ${ }^{5}$, Hussein Abdelaziz Abdalla ${ }^{6}$
}

\footnotetext{
${ }^{1}$ Lecturer of Cardiovascular Medicine, Cardiovascular Department, Mansoura Faculty of Medicine, Mansoura, Egypt.

${ }^{2}$ Prof of Biochemistry, Department of medical biochemistry, Mansoura Faculty of Medicine, Mansoura, Egypt.

${ }^{3}$ Lecturer of medical biochemistry, Department of medical biochemistry, Faculty of Medicine, Mansoura university, Egypt Department of Biochemistry, College of Medicine, Almaarefa University, Riyadh, Saudi Arabia.

${ }^{4}$ Demonstrator of medical biochemistry Department, Mansoura Faculty of Medicine, Mansoura, Egypt.

${ }^{5}$ Lecturer of Public Health and Preventive Medicine, Public Health \& Community Medicine Department, Mansoura Faculty of Medicine, Mansoura, Egypt.

${ }^{6}$ Prof of Biochemistry, Department of Medical Biochemistry, Faculty of Medicine, Taibah University, Saudi Arabia. Department of medical biochemistry, Mansoura Faculty of Medicine, Mansoura, Egypt.
}

Submit Date: Dec 31, 2021

Revise Date: Feb 20, 2021

Accept Date: March 24, 2021

\section{Keywords}

- Paraoxonase 1

(PON1)

Polymorphisms

- Coronary heart disease Egyptians

\section{Abstract}

Background: Coronary heart disease (CHD) is the leading cause of morbidity and mortality worldwide. There are many risk factors for CHD but recently the role of oxidative stress in progression of atherosclerosis has been more recognized. Paraoxonase 1 (PON1) protects against oxidation of LDL and many polymorphisms in both of exons and promoter regions of (PON1) gene have been investigated for their association with CHD. The aim of the present study was to investigate the relation between CHD suceptibility and PON1 Q192R (A/G) gene polymorphism in a cohort of Egyptian individuals. Methods: The study included 100 subjects, 50 patients who admitted to cardiovascular department with established diagnosis of obstructive coronary artery disease by coronary angiography and 50 healthy participants. Genotyping of PON1 Q192R (A/G) was done, and then serum concentration of PON1 was assessed by ELISA after that by spectrophotometer. Results: Serum PON1 enzyme was lower in patients with CHD than in control group with a statistically significant difference $p<0.001$. A statistically significant association was observed with $\mathrm{AG}$ and GG genotypes of PON1 gene with CHD with $\mathrm{P}=0.003$, $\mathrm{OR}=5.02(95 \% \mathrm{CI}=1.66-15.26)$ and $\mathrm{P}=0.038, \mathrm{OR}=9.4(95 \% \mathrm{CI}=1.07-82.5)$; respectively. The $\mathrm{G}$ allele of PON1 was higher in CHD patients than controls suggesting that this allele may demonstrate a susceptibility effect to $\mathrm{CHD}$ in our cohort with $\mathrm{P}<0.001$, OR $=5.16(95 \% \mathrm{CI}=2.1$ 12.5) Conclusion: The Q192R polymorphism in the PON1 gene may be a susceptibility gene associated with increased risk of CHD among Egyptians.

Corresponding author: Sherif Arafa: Lecturer of Cardiovascular Medicine, Cardiovascular Department, Mansoura Faculty of Medicine, Mansoura, Egypt. Email: dr_sherifarafa1981@hotmail.com. Tel: 01001328414 


\section{INTRODUCTION}

Coronary heart disease (CHD) is the leading cause of morbidity and mortality all over the world. The incidence of CHD is rising, and it comes to be a true pandemic. (1), (2). The agerelated death rates from $\mathrm{CHD}$ are declining in many developed countries and increasing in the developing countries as a result of variations in demographic, urbanization and lifestyle (3),(4) . In Egypt, CHD is a major health problem with the incidence of deaths about $40 \%$ of total deaths through the Egyptian population (5). CHD has multiple risk factors including age, dyslipidaemia, diabetes mellitus, hypertension, sedentary lifestyle, smoking and obesity. The role of Oxidative stress in the initiation and progression of atherosclerosis and CHD has gain attention in the last few decades. (6) The newer risk factors for CHD such as the genetic factors e.g mutations at specific chromosomal locations and single nucleotide polymorphisms (SNPs) (3) is necessary to be included with the classical risk factors to improve the ability to expect future risk and determine the treatment plan for those patients .(7) Paraoxonase 1 (PON1) is a glycoprotein synthesized in the liver and secreted in the blood where it is related to high-density lipoprotein (HDL) cholesterol in the circulation. It has antioxidant properties, through protection of low density lipoprotein cholesterol (LDL-C) and HDL-C against oxidation, it also suppress the monocytes differentiation into macrophages, so limiting the process of foam cell formation and atherosclerosis. As a result (PON1) became the focus of intensive research both at phenotypic and genetic levels. (8) (9).PON1 gene is situated in the long arm of chromosome 7 at q21.3. It has 9 exons and it is $26 \mathrm{~kb}$ in length.
More than 200 single nucleotide polymorphisms (SNPs) have been defined for this gene. Multiple polymorphisms in exons and promoter regions of PON1 gene have been explored in many researches for their association with CHD. It had been proposed that low serum PON 1 concentration and PON1 Q192R (A/G) polymorphism- that is an amino acid replacement at codon 192 glutamine (Q) to arginine (R)- might be risk factor for atherosclerosis and development of CHD (10). To our knowledge, the studies that were conducted to evaluate the association between PON1 Q192R polymorphism with the CHD among Egyptian population are deficient. So, the present study was undertaken to assess the correlation between polymorphism of PON1 Q192R and CHD in Egypt.

\section{Methods:}

2.1. Study Population: A hospital based matched case control study was conducted during the period from August 2018 to August 2019. The study included a convenient sample of 100 subjects. 50 patients who admitted to cardiovascular department complaining of chest pain with established diagnosis of obstructive coronary artery disease by coronary angiography. Coronary angiography showed $70 \%$ or more stenosis in one or more coronary arteries are considered to have obstructive CAD (11). Patients with congenital heart disease, rheumatic heart disease, end stage renal disease, or advanced liver cirrhosis are excluded from this study. Control group included 50 healthy participants. A control was defined as age and sex matched subjects with no clinical evidence of CHD. They were recruited from other departments (such as ophthalmology, blood banks and outpatient clinics). Eligibility criteria for control include: fully conscious, co-operative, and 
well-oriented with time, place, and person, who voluntary agree to participate in the study. All patients and controls were from Egypt with both Egyptian parents.

2.2. Study Tool: An interviewer-administered structured questionnaire was done and including socio-demographic characteristics such as age, sex, physical examination. Coronary angiography was done for all patients. Laboratory investigations were done as blood samples $(5 \mathrm{ml})$ were collected from antecubital vein of both patients and control subjects between 8-10 a.m after a 12-h overnight fasting. Each sample was divided as following: a) $2 \mathrm{ml}$ were delivered to a test tube containing 200 $\mu 1$ EDTA to prevent blood coagulation and stored at $-20{ }^{\circ} \mathrm{C}$ until DNA extraction for genotyping. (b) $2 \mathrm{ml}$ were collected in a tube with a clot activator and serum gel separator for ELISA for estimation of serum PON 1 enzyme concentration (c) $1 \mathrm{ml}$ blood was collected in sterilized dry tube for lipid profile.

\section{Typing of PON1 Q192 R (rs 662) gene polymorphisms:}

Genomic DNA was extracted from whole venous EDTA blood using INTRON G-spin ${ }^{\text {TM }}$ Total DNA Extraction Kit. The PON1 Q192 R (rs 662) polymorphism was genotyped by PCR based restriction fragment length polymorphism (RFLP) according to the method of Hasselwander et al. with some modifications (12). PCR amplification of the region containing $\mathrm{A} / \mathrm{G}$ polymorphism in PON 1 gene was carried out with the following primers: $\quad$ Forward 5TATTGTTGCTGTGGGACCTGAG-3 and Reverse 5-CACGCTAAACCCAAATACATCTC3. Reaction volume was $25 \mu 1: 6 \mu \mathrm{DNA}$ at 10 ng/ $\mu 1,12.5 \mu 12 \mathrm{X}$ Taq PCR Tiangen master mix, Tiangen Bioline, Beijing, China, Cat. no: KT201), $0.5 \mu 1$ of each primer $(10 \mathrm{pmol} / \mu \mathrm{l})$, and $5.5 \mu 1$ $\mathrm{H}_{2} \mathrm{O}$. Reactions were carried out in thermocycler (Techne TC-312, UK) with the following cycling parameters: an initial denaturation at $95{ }^{\circ} \mathrm{C}$ for 5 min followed by 35 cycles of $95{ }^{\circ} \mathrm{C}$ for $1 \mathrm{~min}, 58$ ${ }^{\circ} \mathrm{C}$ for $1 \mathrm{~min}$, and $72{ }^{\circ} \mathrm{C}$ for $1 \mathrm{~min}$ and a final extension at $72 \mathrm{C}$ for $10 \mathrm{~min} .10 \mu \mathrm{l}$ of PCR products were resolved in $2.5 \%$ agarose gel to check the PCR products with 50 bp DNA ladder (INtron Biotechnology Inc, South Korea, Cat. no: 24072). The electrophoresis apparatus was adjusted at 100 volts and the run lasted for 45 minutes, the gel visualized with transilluminator. Appearance of sharp bands near 100 bp band of ladder indicates correct amplification of $99 \mathrm{bp}$ PCR product.

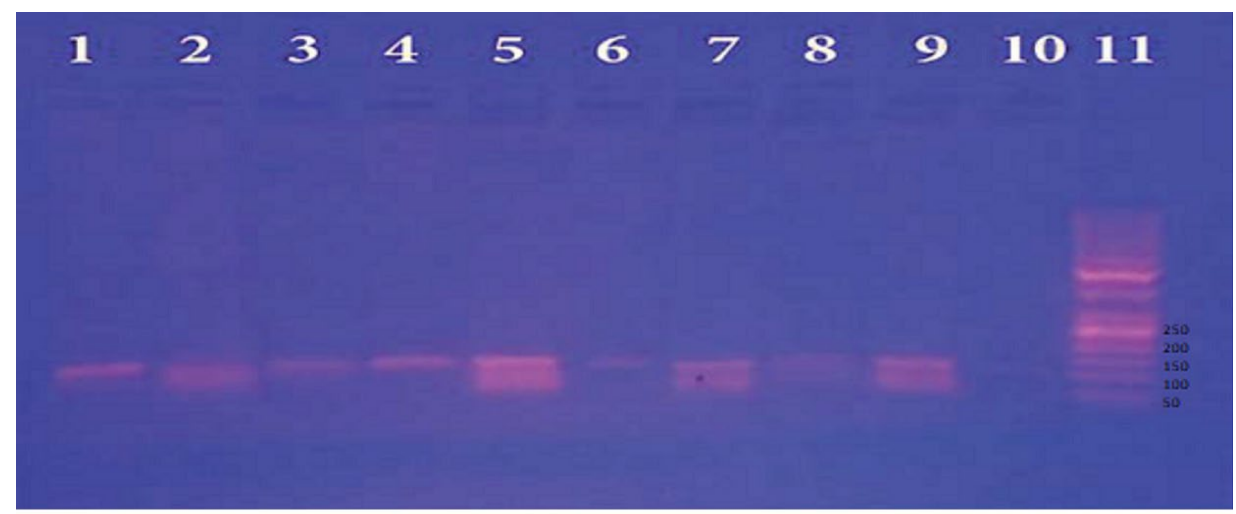

Figure (1) showing visualization of 99 bp PCR product of PON 1 gene by gel electrophoresis (2.5\% agarose gel, Lane 11 represents 50bp DNA ladder, lanes 1-10 PCR products represented by one band at $99 \mathrm{bp}$ ). 
The PCR product was digested with specific restriction endonuclease enzyme AlwI (Thermo Scientific BspPI AlwI Thermo Fisher scientific Inc, Eu). AlwI restriction enzyme had one recognition site in the $G$ allele but no recognition site in the A allele within the amplified region generating various length fragments that were characteristic for this SNP. These fragments were separated by using gel electrophoresis.

$20 \mu 1$ total volume reaction was prepared by mixing: $10 \mu \mathrm{l}$ of PCR products, $1 \mu 1$ of restriction enzyme, $2 \mu 1$ 10X FastDigest green buffer, and $7 \mu 1$ nuclease- free water. The mixture was incubated at $55{ }^{\circ} \mathrm{C}$ for 3 hours followed by heating at $80{ }^{\circ} \mathrm{C}$ for 20 minutes. The transversion of the A nucleotide into G nucleotide in the $99 \mathrm{bp}$ PCR-product creates only one recognition sites for AlwI restriction endonuclease cutting PCR product into 69 and $30 \mathrm{bp}$ fragments. After digestion, products were separated on $3 \%$ agarose gel with 50 bp ladder. The gel was run at 80 volts for 1 hour, after completion sharp bands were checked and photographed.

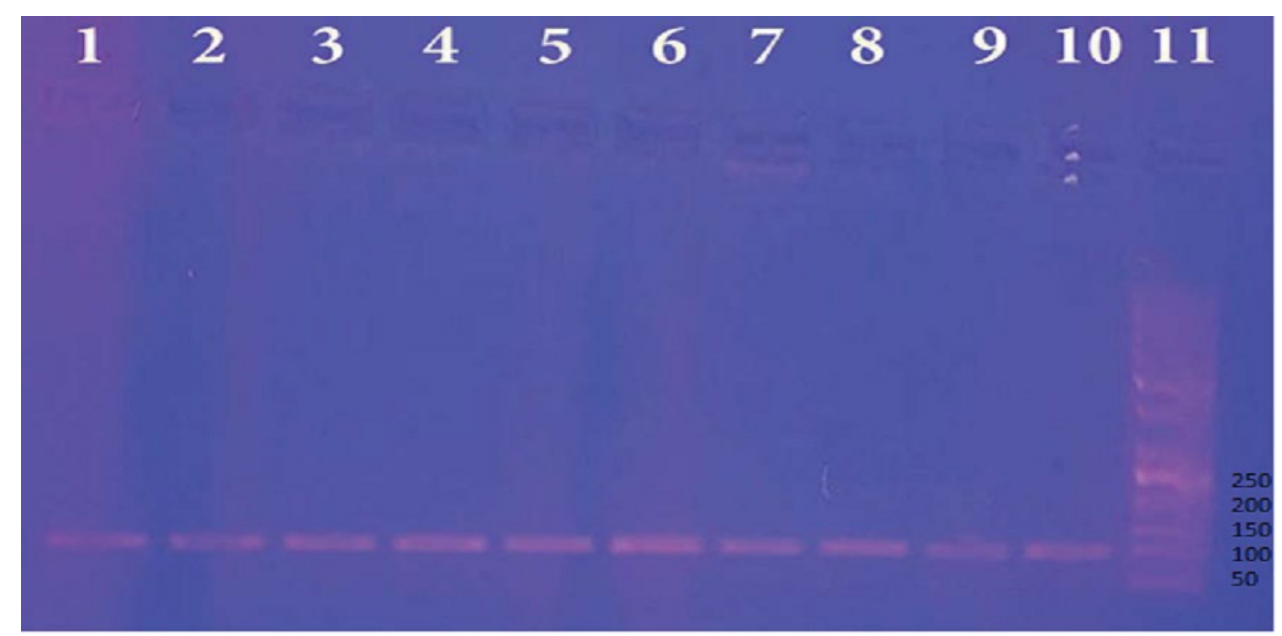

Figure (2): showing visualization of RFLP analysis of rs662 polymorphism , 3\% agarose gel electrophoresis ; lane 11 represents $50 \mathrm{bp}$ ladder, there are two bands (69 bp and $30 \mathrm{bp}$ ) GG genotype in lanes 7, 8, 9, three bands (99bp, 69bp, and 30bp) AG genotype in lane 5, and one band (99 bp) AA genotype in lanes 1,2,3,4,6.

2.3. Ethical Consideration. Subjects gave their consent to participate in the study. All the information that was obtained about the subjects was kept confidential. Study protocol was approved by Institution Research Board (IRB) of our medical college number: MS.16.06.48.

2.4. Data analysis: Data were entered, cleaned to identify inconsistencies and statistically analyzed using the Statistical Package for Social Science (SPSS) version 16. The normality of data was first tested with one-sample Kolmogorov-Smirnov test. Qualitative data was described using number and percent. Association between categorical variables was tested using Chi-square test. When more than $25 \%$ of the cells have expected count less than 5 , Fisher's exact test was used. Continuous variables were presented as mean $\pm \mathrm{SD}$ (standard deviation). Independent sample t- test was used to compare means (parametric data). Deviations from HardyWeinberg equilibrium expectations were determined using the chi-squared test at a significance level of $\mathrm{P}<0.05$. Polymorphisms and genotype frequencies were evaluated by gene counts. The data were tested for the goodness of fit 
between the observed and expected genotype frequencies (X2 test). When the observed genotype frequencies fit to Hardy-Weinberg equilibrium, X2 tests (2-by-2 tables) were performed to calculate significantly different genotype distributions between patients and controls and also odd's ratio(OR) and confidence interva195\% were calculated to detect risk ratio. A $\mathrm{P}$ value $<0.05$ was considered statistically significant in all analyses.

\section{Results:}

Table (1) showed that both cases and control groups were matched regarding all their sociodemographic characteristics. There was statistically significant association between the presence of hypertension, diabetes and current history of smoking with $\mathrm{CHD}(\mathrm{OR}=3.01,4.09$ and 3.3., respectively).

Serum PON1 concentration was statistically significantly higher in control group than CHD cases, $\mathrm{p}$ value $<0.001$. Lipid profile analysis in both studied groups showed significantly higher TC, TG, LDL-C level $(p<0.0001)$.and lower HDL-C level in cases compared to controls, $\mathrm{P}=$ 0.04 as shown in table (2)

There was a significant difference between CHD patients and control in the allelic distribution of the PON1 $(\mathrm{P}<0.001 *)$, Therefore, the G allele of PON1 was higher in CHD patients than controls suggesting that this allele may demonstrate a susceptibility effect to $\mathrm{CHD}$ in our cohort $(\mathrm{OR}=$ $5.16(95 \% \mathrm{CI}=2.1-12.5)$ as shown in tables (3) .A statistically significant association was observed with AG and GG genotypes of PON1 gene with
CHD with $\mathrm{OR}=5.02(95 \% \mathrm{CI}=1.66-15.26)$ and 9.4 $(95 \% \mathrm{CI}=1.07-82.5)$; respectively.

Table (4) showed that in both CHD patients and control groups, there was highly significant changes between AA, AG and GG genotypes as regard to serum PON1 concentration in each group (patients and controls) $(\mathrm{p}<0.001$ for each). On the other hand, serum PON 1 level was higher in control group with AA and AG genotypes with statistically significant difference.

There was no statistically significant difference between AA, AG and GG genotypes as regard to total cholesterol, triglyceride, HDL and LDL in each group (patients and controls) with $(\mathrm{p}=0.33,0.8),(\mathrm{p}=0.1,0.38),(\mathrm{p}=0.15,0.86)$ and $(\mathrm{p}=0.4,0.69)$; respectively.

On the other hand, cholesterol, triglyceride and LDL were higher in patient group with AA and $A G$ genotypes than control group with statistically significant difference .HDL was found higher in control group with AA genotype than control group with statistically significant difference.

Table (5) showed that Both A \& G alleles showed significant higher PON1 levels in control than CHD patients groups $(\mathrm{P}<0.001,0.003$; respectively). Both A \&G alleles showed significant higher cholesterol, triglyceride and LDL levels in CHD patients than control groups $(\mathrm{P}<0.001$ for each), $(\mathrm{P}<0.001$ for each $)$ and $(\mathrm{p}$ $<0.001,0.003$ ); respectively .Moreover A alleles showed significant higher HDL levels in control than patients groups with $\mathrm{p}=0.002$. 
Table (1): Socio-demographic and clinical features of cases versus controls

\begin{tabular}{|c|c|c|c|c|}
\hline $\begin{array}{c}\text { Socio-demographic } \\
\text { characteristics }\end{array}$ & $\begin{array}{c}\text { Cases }=50 \\
\mathrm{~N}(\%)\end{array}$ & $\begin{array}{c}\text { Controls }=50 \\
\text { N (\%) }\end{array}$ & Significance test & OR(95\%CI) \\
\hline Age (Mean \pm SD) & $\mathbf{5 5 . 2 4} \pm 8.17$ & $\mathbf{5 4 . 3 8} \pm 6.77$ & $\mathrm{t}=-0.2, \mathrm{P}=0.84$ & - \\
\hline $\begin{array}{l}\text { Sex } \\
\text { Female (r) } \\
\text { Male }\end{array}$ & $\begin{array}{c}36(72) \\
14(28)\end{array}$ & $\begin{array}{l}36(72) \\
14(28)\end{array}$ & Not applicable & Undefined \\
\hline $\begin{array}{l}\text { DM } \\
\text { No (r) } \\
\text { Yes } \\
\end{array}$ & $\begin{array}{l}30(60) \\
20(40)\end{array}$ & $\begin{array}{l}43(86) \\
7 \quad(14) \\
\end{array}$ & $\chi^{2}=8.6, P=0.003$ & $4.09(1.5-10.8)$ \\
\hline $\begin{array}{l}\text { HTN } \\
\text { No } \\
\text { Yes }\end{array}$ & $\begin{array}{l}23(46) \\
27(54)\end{array}$ & $\begin{array}{l}36(72) \\
14(28)\end{array}$ & $\chi^{2}=6.9, P=0.008$ & $3.01(1.3-6.9)$ \\
\hline $\begin{array}{l}\text { Smoking } \\
\text { Never smoked } \\
\text { Ex-smoker } \\
\text { Current smoker }\end{array}$ & $\begin{array}{ll}16(32) \\
5(10) \\
29(58) \\
\end{array}$ & $\begin{array}{c}31(62) \\
2(4) \\
17(34) \\
\end{array}$ & $\begin{array}{c}- \\
\text { FET }, \mathrm{P}=0.09 \\
\chi 2=7.8, \mathrm{P}=0.005\end{array}$ & $\begin{array}{c}1 \\
4.8(0.8-27.7) \\
3.3(1.4-7.7)\end{array}$ \\
\hline
\end{tabular}

t: student t test , FET: Fisher's exact

Table (2): Serum PON 1 level and lipid profile among cases versus controls

\begin{tabular}{|l|c|c|l|}
\hline \multirow{2}{*}{ PON 1 and lipid profile } & \multicolumn{1}{|c|}{ Cases } & Controls & P value \\
\hline Serum PON1(ng/ml) & $0.166 \pm 0.059$ & $0.228 \pm 0.042$ & $<0.001^{*}$ \\
\hline Cholesterol $(\mathrm{mg} / \mathrm{dl})$ & $238.31 \pm 40.66$ & $5.88 \pm 15.68$ & $<0.001^{*}$ \\
\hline T.G $(\mathrm{mg} / \mathrm{dl})$ & $199.52 \pm 25.10$ & $132.57 \pm 18.01$ & $<0.001^{*}$ \\
\hline HDL-C $(\mathrm{mg} / \mathrm{dl})$ & $50.86 \pm 10.53$ & $55.30 \pm 10.95$ & $0.04^{*}$ \\
\hline LDL-C $(\mathrm{mg} / \mathrm{dl})$ & $145.70 \pm 40.69$ & $95.95 \pm 11.24$ & $<0.001^{*}$ \\
\hline
\end{tabular}

Table (3): Distribution of PON1 Q192 R ( rs 662) alleles and genotypes in CHD cases versus controls.

\begin{tabular}{|c|c|c|c|c|}
\hline $\begin{array}{l}\text { PON1 } \\
\text { Polymorphism }\end{array}$ & $\begin{array}{l}\text { Cases } \\
(\mathbf{N}=\mathbf{5 0}) \\
\mathbf{N}(\%)\end{array}$ & $\begin{array}{l}\text { Controls } \\
(\mathbf{N}=50) \\
\mathbf{N}(\%)\end{array}$ & Significance test & OR (95\% CI) \\
\hline $\begin{array}{l}\text { Alleles }(\mathbf{n}=100) \\
\text { A (r) } \\
\text { G }\end{array}$ & $\begin{array}{l}72(72) \\
28(28)\end{array}$ & $\begin{array}{c}93(93) \\
7(7)\end{array}$ & $\chi^{2}=15.3, P<0.001^{*}$ & $\begin{array}{c}1 \\
5.16(2.1-12.5)\end{array}$ \\
\hline $\begin{array}{l}\text { Genotypes } \\
\text { AA (r) } \\
\text { AG } \\
\text { GG }\end{array}$ & $\begin{array}{l}28(56) \\
16(32) \\
6 \quad(12)\end{array}$ & $\begin{array}{l}44(88) \\
5(10) \\
1 \quad(2)\end{array}$ & $\begin{array}{l}\chi^{2}=\overline{9} .07, \mathrm{P}=0.003^{*} \\
\text { FET }, \mathrm{P}=0.038^{*}\end{array}$ & $\begin{array}{c}1 \\
5.02(1.66-15.26) \\
9.4(1.07-82.5)\end{array}$ \\
\hline
\end{tabular}


Table (4): Comparison of Serum PON1 and lipid profile between both patient and control groups in different genotypes

\begin{tabular}{|c|c|c|c|c|c|c|c|c|c|c|}
\hline & \multicolumn{3}{|c|}{ Patient (50) } & \multirow[t]{2}{*}{ P1 } & \multicolumn{3}{|c|}{ Control (50) } & \multirow[t]{2}{*}{ P2 } & \multirow[t]{2}{*}{ P3 } & \multirow[t]{2}{*}{ P4 } \\
\hline & $\mathbf{A A}$ & AG & GG & & $\mathbf{A A}$ & $\mathbf{A G}$ & GG & & & \\
\hline $\begin{array}{l}\text { Serum } \\
\text { PON1 } \\
\text { Mean } \\
+/- \text { SD }\end{array}$ & $\begin{array}{l}0.202 \\
0.055\end{array}$ & $\begin{array}{l}0.128 \\
0.009\end{array}$ & $\begin{array}{l}0.99 \\
0.13\end{array}$ & $<0.001 *$ & $\begin{array}{l}0.238 \\
0.033\end{array}$ & $\begin{array}{l}0.161 \\
0.022\end{array}$ & $\begin{array}{c}0.123 \\
-\end{array}$ & $\begin{array}{c}<0.001 \\
*\end{array}$ & $<0.001^{*}$ & $<0.001 *$ \\
\hline $\begin{array}{l}\text { Cholesterol } \\
\text { Mean } \\
+/- \text { SD }\end{array}$ & $\begin{array}{c}245.47 \\
42.90\end{array}$ & $\begin{array}{c}231.77 \\
40.98\end{array}$ & $\begin{array}{c}222.33 \\
22.6\end{array}$ & 0.33 & $\begin{array}{c}175.93 \\
16.23\end{array}$ & $\begin{array}{c}173.62 \\
12.43\end{array}$ & $\begin{array}{c}184.8 \\
-\end{array}$ & 0.8 & $<0.001$ & 0.006 \\
\hline $\begin{array}{l}\text { TG } \\
\text { Mean } \\
+/- \text { SD }\end{array}$ & $\begin{array}{c}208.11 \\
21.35\end{array}$ & $\begin{array}{c}191.38 \\
27.93\end{array}$ & $\begin{array}{c}181.17 \\
18.49\end{array}$ & 0.1 & $\begin{array}{c}132.63 \\
18.34\end{array}$ & $\begin{array}{c}127.52 \\
14.10\end{array}$ & 155 & 0.38 & $<0.001$ & $<0.001$ \\
\hline $\begin{array}{l}\text { LDL } \\
\text { Mean } \\
+/- \text { SD }\end{array}$ & $\begin{array}{c}152.25 \\
41.81\end{array}$ & $\begin{array}{l}138.5 \\
43.29\end{array}$ & $\begin{array}{c}134.33 \\
24.59\end{array}$ & 0.4 & $\begin{array}{l}96.45 \\
11.57\end{array}$ & $\begin{array}{c}91.92 \\
9.17\end{array}$ & $\begin{array}{c}94.00 \\
-\end{array}$ & 0.69 & $<0.001$ & 0.03 \\
\hline $\begin{array}{l}\text { HDL-c } \\
\text { Mean } \\
+/- \text { SD }\end{array}$ & $\begin{array}{c}48.43 \\
8.02\end{array}$ & $\begin{array}{l}54.75 \\
14.11\end{array}$ & $\begin{array}{c}51.83 \\
7.73\end{array}$ & 0.15 & $\begin{array}{l}55.00 \\
11.41\end{array}$ & $\begin{array}{c}57.22 \\
7.78\end{array}$ & $\begin{array}{c}59.00 \\
-\end{array}$ & 0.86 & 0.006 & 0.7 \\
\hline
\end{tabular}

SD: standard deviation $\quad$ P: Probability *: significance $<0.05$

P1: For comparison between genotypes in patients group

P2: for comparison between genotypes in control group

P3: For comparison between Patient \& control group in AA genotype

P4: For comparison between Patient \& control group in AG genotype

Table (5): Comparison of Serum PON1 and lipid profile between both patient and control groups in different alleles

\begin{tabular}{|c|c|c|c|c|c|c|c|c|}
\hline & & & P1 & & & P2 & P3 & P4 \\
\hline & A & G & & $\mathbf{A}$ & $\mathbf{G}$ & & & \\
\hline $\begin{array}{l}\text { Serum } \\
\text { PON1 } \\
\text { Mean } \\
+/- \text { SD }\end{array}$ & $\begin{array}{l}0.185 \\
0.057\end{array}$ & $\begin{array}{l}0.116 \\
0.018\end{array}$ & $\begin{array}{c}<0.001 \\
*\end{array}$ & $\begin{array}{l}0.234 \\
0.036\end{array}$ & $\begin{array}{l}0.150 \\
0.026\end{array}$ & $<0.001 *$ & $<0.001 *$ & $0.003 *$ \\
\hline $\begin{array}{l}\text { Cholesterol } \\
\text { Mean } \\
+/- \text { SD }\end{array}$ & $\begin{array}{c}242.43 \\
42.28\end{array}$ & $\begin{array}{c}227.73 \\
33.75\end{array}$ & 0.1 & $\begin{array}{c}175.81 \\
15.91\end{array}$ & $\begin{array}{c}176.81 \\
11.52\end{array}$ & 0.87 & $<0.001$ & $<0.001$ \\
\hline $\begin{array}{l}\text { TG } \\
\text { Mean } \\
+/- \text { SD }\end{array}$ & $\begin{array}{c}204.39 \\
23.68\end{array}$ & $\begin{array}{c}187.00 \\
24.22\end{array}$ & 0.001 & $\begin{array}{c}132.36 \\
18.01\end{array}$ & $\begin{array}{c}135.37 \\
17.67\end{array}$ & 0.67 & $<0.001$ & $<0.001$ \\
\hline $\begin{array}{l}\text { LDL } \\
\text { Mean } \\
+/- \text { SD } \\
\end{array}$ & $\begin{array}{c}149.19 \\
41.94\end{array}$ & $\begin{array}{c}136.71 \\
35.63\end{array}$ & 0.17 & $\begin{array}{l}96.21 \\
11.40\end{array}$ & $\begin{array}{c}92.51 \\
7.55\end{array}$ & 0.4 & $<0.001$ & 0.003 \\
\hline $\begin{array}{l}\text { HDL-c } \\
\text { Mean } \\
+/- \text { SD }\end{array}$ & $\begin{array}{c}49.83 \\
9.90\end{array}$ & $\begin{array}{l}53.50 \\
11.62\end{array}$ & 0.11 & $\begin{array}{l}55.12 \\
11.16\end{array}$ & $\begin{array}{c}57.73 \\
6.41\end{array}$ & 0.54 & 0.002 & 0.36 \\
\hline
\end{tabular}

SD: standard deviation $\quad P$ : Probability *: significance $<0.05$

P1: For comparison between Alleles in patients group

P2: for comparison between Alleles in control group

P3: For comparison between Patient \& control group in A Allele

P4: For comparison between Patient \& control group in $G$ Allele 


\section{Discussion:}

Coronary heart disease is a global health problem with increasing magnitude over time. Many traditional risk factors for atherosclerosis are present but novel risk factors like genetic polymorphisms are recently investigated. PON1 is a glycoprotein synthesized in the liver and secreted in the blood where it is related to HDL-C in the circulation. It has antioxidant properties, through protection of LDL-C and HDL-C against oxidation, it also suppress the monocytes differentiation into macrophages, so limiting the process of atherosclerosis. Our study was carried out on 50 patients who were diagnosed formerly with CHD and admitted to Cardiology Unit in our university hospital and 50 age matched healthy non-cardiac subjects. At first genotyping of PON1 Q192R (A/G) was done, and then serum concentration of PON1 was assessed by ELISA after that by spectrophotometer. Lipid profile was done for the cases and control groups. These procedures were conducted in laboratories of Biochemistry Department. In this study, analysis of genotype frequency for PON1 Q192R polymorphisms revealed statistically significant difference between CHD patients and controls with higher prevalence of GG genotype and the $G$ $(\mathrm{R})$ allele of PON1 Q192R $(\mathrm{A} \rightarrow \mathrm{G})$ polymorphism in CHD patients. These results are in agreement with a study conducted in Saudi Arabia by Hassan et al. that showed the frequency of $A G$ and $G G$ genotypes in CHD patients was increased compared to controls and accordingly a significant association of the Q192R $(A \rightarrow G)$ polymorphism with CHD (9) .Also, these findings were in agreement with Randa et al. (13) in Egypt who mentioned that PON1 GG genotype individuals had 9 times higher risk of CHD, while PON1 AG genotype individuals had a 4 times higher risk of CHD. Similar results were obtained in studies conducted on patients suffering from ischemic strokes, in whom the PON1 192 GG genotype was correlated with the risk of stroke (14). In addition Gupta et al. (15) found that the frequency of 192 $\mathrm{G}$ allele was significantly higher in CHD patients and that variants of $192 \mathrm{AG}$ and $192 \mathrm{GG}$ were accompanied with high risk of CHD. Also, a significant association between PON1 Q192R $(\mathrm{A} \rightarrow \mathrm{G})$ polymorphism and Coronary artery diseases and PON1 $192 \mathrm{G}$ allele as an important risk factor for CHD has been also found by Chen et al in China(16) and Munshi et al. in India(17). Logistic regression analysis of the data of Kaur et al. in India revealed that the heterozygous genotype (AG) in the PON1 gene might be associated with an about 1.6 fold augmented risk of developing CAD in an Indian population (odds ratio $[\mathrm{OR}]=1.59,95 \% \mathrm{CI}=1.19-2.12, \mathrm{p}<$ 0.0001) (18).

In contrast, some studies didn't find evidences for the changes of PON1 and the association between Q192R polymorphism and CVDs risk (19). Mackness et al stated that CVD was associated with the activity and concentration of paraoxonase1 but not its genotype (20). Furthermore, in EPIC Norfolk Prospective Population Study, neither PON1 Q192R polymorphism nor activity of PON1 predicted future risk of CHD (21). Moreover, there was no significant correlation between PON1 L55M or Q192R $(A \rightarrow G)$ polymorphisms and susceptibility to CHD (22). In addition, a study in France by Martínez et al. (23) revealed that there was no significant difference between the AA and AG/GG 
genotypes in both the clinical variables and extent of CAD. These divergences between the data obtained from the different studies might be caused by methodological, environmental and life style factors. Alteration of the association between PON1 polymorphism and the risk of CHD by gene-gene interactions and/or gene-environmental factors can be the cause for such diverse results. In the present study, the serum concentration of PON1 was significantly higher in control group than patient group, and its level was significantly higher in control group with AA (QQ) and AG (QR) genotypes. These findings were in accordance with Hampe et al. (24) who mentioned that activity of arylesterase of PON1 which represents PON1 enzyme concentration was significantly lower in CHD patients in comparison to control group. Moreover, PON1 activity and its serum concentration in the studied individuals were lower in CHD patients than in the control subjects. This result might be elucidated by several polymorphisms that have been reported for PON1 genes in the coding and the promotor regions that affect enzyme activities and /or concentrations to a greater or lesser extent (20).A significant relationship had been found between the activity and concentration of PON1 and coronary atherosclerosis expressed as quantitative angiographic indexes of severity, extent, and overall atheroma burden of CHD. Individuals with lowest activity and concentration of PON1 had a more severe CHD than individuals with highest PON1 activity and concentration. $(25,26)$

Conclusion: Paraoxonase 1 levels in blood and PON 1 gene polymorphisms may promote to the susceptibility of individuals to CHD. AG and GG genotypes of PON1 gene can be considered risk factors for the development of CHD among Egyptians. Additional rigorous design, wide scale and multicenter studies, large sample of casecontrol, or prospective study are necessary to evaluate and investigate the relationship between gene polymorphisms -either alone or combinedand the occurrence of CHD among Egyptian population.

Study limitations: This study is a group matched case control study design and the results are restricted to the subgroup of survivors of CHD but not to the whole group of CHD patients, these observations need further confirmation using prospective study design. Also, the single center hospital based study that doesn't reflect the national situation at the community level.

\section{Abbreviations:}

CHD: Coronary Heart Disease

HDL-C: High density lipoprotein cholesterol

PON1: Paraoxonase 1

LDL-C: Low density lipoprotein cholesterol

EDTA: Ethylene di-amine tetra acetic acid

ELISA: Enzyme-linked immunosorbent assay

RFLP: Restriction fragment length polymorphism

PCR: Polymerase chain reaction

DNA: Deoxyribonucleic acid

SNP: Single-nucleotide polymorphism

IRB: Institution Research Board

SPSS: Statistical Package for Social Science

OR: Odd's ratio

TC: Total cholesterol

TG: Triglycerides

CVD: Cardiovascular disease

IHD: Ischemic heart disease 


\section{References:}

1) Edelman J, Bannon $P$ and Vallely M (2012):Letter by Ahmed regarding article : second internal thoracic artery versus radial artery in coronary artery bypass grafting a longterm propensity score matched follow up study. Circulation ;125 (17): 630 .

2) Liu, D., Jiang, Z., Dai, L., Zhang X,Han Y,Yan C (2014):Association between the 786TC 1polymorphism in the promoter region of endothelial nitric oxide synthase (eNOS) and risk of coronary artery disease: a systematic review and metaanalysis. Gene ;545 (1):175-183.

3) Hassanin N, Gharib S, El Ramly M, Meged $M$ and Makram A (2015) : Metabolic syndrome and coronary artery disease in young Egyptians presenting with acute coronary syndrome. Kasr Al Ainy Medical Journal ; (1): 21- 27.

4) Almahmeed W, Arnaout MS, Chettaoui R, Ibrahim M, Kurdi MI, Taher MA, et al (2012) :Coronary artery disease in Africa and the Middle East. Clinical Risk Managment; 8:65-72.

5) Turk-Adawi, K, Sarrafzadegan N,Fadhil I,Taubert K,Masoumeh M (2018):Cardiovascular disease in the Eastern Mediterranean region: epidemiology and risk factor burden. Nature Reviews Cardiology ;15(2): 106.

6) Fearon I and Faux S (2009): Oxidative stress and cardiovascular disease: novel tools give (free) radical insight. Journal of molecular and cellular cardiology ; 47 : 372-381.

7) Wilson PWF (2008): Progressing From Risk Factors to Omics. Circulation: Cardiovascular Genetics;1(2):141-146.

8) Khalil, A., Fulop, T., \& Berrougui, $\boldsymbol{H}$. (2021). Role of paraoxonase1 in the regulation of high-density lipoprotein functionality and in cardiovascular protection. Antioxidants \& redox signaling, 34(3), 191-200.

9) Hassan M A.,Al-Attas OS,Hussain T,Al Daghri NM (2013) :The Q192R polymorphism of the paraoxonase 1 gene is a risk factor for coronary artery disease in Saudi subjects. Molecular and cellular biochemistry; 380(1-2): 121-128.

10) El-Lebedy D, Kafoury M, Ibrahim A, Abd-ElHaleem D, Awadallah $E$ and Ashmawy E (2014): Paraoxonase 1-gene Q192R and L55M polymorphisms and risk of cardiovascular disease in Egyptian patients with type 2 diabetes mellitus. Journal of Diabetes and metabolic disorders; 13(1): 125.

\section{1) Matam K,Khan I,Hasan Q, Roa} $\mathbf{P ( 2 0 1 5 ) : C o r o n a r y ~ a r t e r y ~ d i s e a s e ~ a n d ~ t h e ~}$ frequencies of MTHFR and PON1 gene polymorphism studies in a varied population of Hyderabad, Telangana region in south India. Journal of King Saud University-Science ;27(2): 143-150.

12) Hasselwander, O., Savage, D. A., Mcmaster, D., Loughrey, C. M., Mcnamee, P. T., Middleton, D., ... \& Young, I. S. (1999). Paraoxonase 
polymorphisms are not associated with cardiovascular risk in renal transplant recipients. Kidney international, 56(1), 289-298.

13) Randa H, Tarek A,Rehab K,Rasha M (2010):The relationship between Paraoxonase 1-192 polymorphism and activity with coronary artery disease .Clinical biochemistry;43:553-558.

14) Demirdogen

$$
\text { B.C,Turkanoglu A.,Bek }
$$

S.,Sanisoglu

Y.,Demirkaya

$S$

(2008):Paraoxonase/arylesterase ratio,PON1192Q/R polymorphism and PON1 status are associated with increased risk of ischemic stroke.Clinical biochemistry;41(1-2):1-9.

15) Gupta, N.; Gill, K.; Singh, S (2009): Paraoxonases: structure, gene polymorphism \& role in coronary artery disease. Indian Journal of Medical Research; 130:361-368.

16) Chen, H., Ding, S., Zhou, M., Wu, X., Liu, X., Liu, J., ... \& Liu, D. (2018). PON1 L55M and Q192R gene polymorphisms and $\mathrm{CAD}$ risks in patients with hyperlipidemia. Herz, 43(7), 642648.

17) Munshi, R., Panchal, F., Chaurasia, A., \& Rajadhyaksha, G. (2018). Association between Paraoxonase 1 (PON1) gene polymorphisms and PON1 enzyme activity in indian patients with coronary artery disease (CAD). Current Pharmacogenomics and Personalized Medicine (Formerly Current Pharmacogenomics), 16(3), 219-229.
18) Kaur, S., Bhatti, G. K., Vijayvergiya, R., Singh, P., Mastana, S. S., Tewari, R., \& Bhatti, J. S. (2018). Paraoxonase 1 gene polymorphisms (Q192R and L55M) are associated with coronary artery disease susceptibility in Asian Indians. International Journal of Diabetes and Metabolism, 21(1-4), 38-47.

19))Wheeler JG, Keavney BD, Watkins H, Collins R,Danesh J (2004):Four paraoxonase gene polymorphisms in 11212 cases of coronary heart disease and 12786 controls: meta-analysis of 43 studies. Lancet; 363:689-695.

20) Mackness, M.I.; Mackness, B.; Durrington, P.N (2002): Paraoxonase and coronary artery disease. Atherosclerosis Suppl. ;3:49-55.

21) Birjmohun RS, Vergeer M, Stroes ES, Sandhu MS, Ricketts SL, Tanck MW, Wareham NJ, Jukema JW, Kastelein JJ, Khaw KT, Boekholdt SM (2009): Both paraoxonase-1 genotype and activity do not predict the risk of future coronary artery disease; the EPIC-Norfolk Prospective Population Study. PLoS One ;4:6809.

22) Yan-Hong Kang,Hai Yan Loa,Hong Wu, Wei Hua Lai,Xin Xin Li,Xi Yong Yu (2013) : Association of PON1 genotype and haplotype with susceptibility to coronary artery disease and clinical outcomes in dual antiplatelet-treated Han Chinese patients. European journal of clinical pharmacology ;69(8): 1511-1519. 
23) Martínez-Quintana, E, Rodriguez F, Medina-Gil $J$ (2017): Paraoxonase 1 (Q192R) gene polymorphism, coronary heart disease and the risk of a new acute coronary event. Clínical e Investigación en Arteriosclerosis ;29(1): 1-6.

24) Hampe, Mahesh Harishchandra, and Mukund Ramchandra Mogarekar (2014): Paraoxonase1, its Q192R polymorphism and HDL-cholesterol in relation to intensive cardiac care unit stay in ischemic heart disease. Indian journal of human genetics;20(1): 51.

25) Granér, M., James, R. W., Kahri, J., Nieminen, M. S., Syvänne, M., \& Taskinen, M. $\boldsymbol{R}$ (2006) : Association of paraoxonase-1 activity and concentration with angiographic severity and extent of coronary artery disease. Journal of the American College of Cardioloy;47(12): 2429-2435.

26) Mahrooz, A., Shokri, Y., Variji, A., Zargari, M., Alizadeh, A., \& Mehtarian, E. (2021). Improved risk assessment of coronary artery disease by substituting paraoxonase 1 activity for HDL-C: novel cardiometabolic biomarkers based on HDL functionality. Nutrition, Metabolism and Cardiovascular Diseases. 